\title{
BATASAN DAN UKURAN ISTITHA'AHH DALAM BERHAJI MENURUT HUKUM FIQH KONTEMPORER
}

\author{
Said Rizal, Yusriando \\ Universitas Prima Indonesia \\ Jalan Skip, Simpang Sikambing, Medan, Sumatera Utara \\ Email : saidrizal@ unprimdn.ac.id
}

\begin{abstract}
Abstrak
Hajj is a worship that is meant for every Muslim, both men and women with certain conditions. One of these conditions is istitha'ah (able). Istitha'h is the ability to carry out the hajjis in terms of physical health and supplies sufficient to depart and return, as well as supportive security during the pilgrimage and implementation. This discussion aims to determine the boundaries of istitha'ah in the Hajj according to contemporary fiqh. To obtain data in this discussion, a literature study was carried out, namely by studying the Al-Quran, Al-Hadith and fiqh books relating to the chapter of the pilgrimage and other books that are related to the problems in this study. From the results of the discussion it can be seen that, someone who has a healthy body, able to hajj.
\end{abstract}

\section{Keywords: Hajj, Law, Fiqh, Istitha'h, boundary}

\section{Intisari}

Ibadah haji merupakan ibadah yang difardhukan bagi setiap orang Islam, baik laki-laki maupun perempuan dengan syarat-syarat tertentu. Salah satu dari syaratsyarat tersebut adalah istitha'ah (mampu). Istitha'h adalah kemampuan untuk melaksanakan haji yang dilihat dari segi kesehatan fisik dan perbekalan yang cukup untuk berangkat dan kembalinya, serta keamanan yang mendukung selama perjalanan dan pelaksanaan ibadah haji. Pembahasan ini bertujuan untuk mengetahui batasan istitha'ah dalam berhaji menurut fiqh kontemporer. Untuk memperoleh data dalam pembahasan ini, maka dilakukan kajian kepustakaan, yaitu dengan mempelajari AlQuran, Al-Hadis dan kitab-kitab fiqh yang berkaitan dengan bab haji serta buku-buku lain yang ada kaitannya dengan permasalahan dalam penelitian ini. Dari hasil pembahasan dapat diketahui bahwa, seseorang yang mempunyai sehat badan, sanggup berhaji.

Kata kunci : Haji, Hukum, Fiqih, Istitha'h, batasan 


\section{A. Latar Belakang Masalah}

Islam adalah agama yang sempurna, mengatur semua aspek kehidupan manusia, Islam dibangun dengan lima dasar, salah satunya menunaikan ibadah haji ke Baitullah. Ibadah haji merupakan rukun Islam yang kelima, sekaligus merupakan syi' ar di dalam Islam. Mengerjakan haji adalah kewajiban manusia terhadap Allah bagi yang sudah memiliki istitha'ah.

Allah Swt firman:

ولله على الناس حج البيت من الستطاع

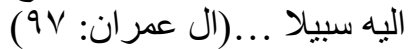
Artinya: “...Mengerjakan haji adalah kewajiban manusia terhadap Allah, bagi orang yang sanggup melakukan perjalanan ke baitullah..." (QS: Ali-Imran: 97)

Berdasarkan ayat di atas, Allah mewajibkan kepada manusia untuk menunaikan ibadah haji, Allah tidak mewajibkan kepada orang-orang yang tidak mampu, ini berarti Allah memaafkan mereka yang tidak mampu. Tetapi bagi yang sanggup mengadakan perjalanan haji yaitu yang telah memenuhi syarat wajib haji, yakni yang sehat jasmani dan rohani, memiliki kemampuan materi berupa biaya perjalanan dan selama perjalanan, serta biaya hidup untuk keluarga yang ditinggal, jalan menuju kesana dan kembalipun aman, tidak ada perang dan juga wabah penyakit. Maka mereka berdosa karena telah menolak panggilan Allah Swt. ${ }^{1}$

\footnotetext{
${ }^{1}$ M. Quraish Shihab, Tafsir al-
} Misbah, Tanggerang: Lentera Hati, 2007, hlm. 160.
Haji berarti pergi menuju kota mekkah untuk mengerjakan ibadah thawaf, sa' $i$ dan wuquf di 'Arafah serta seluruh manasik lainnya. Ibadah tersebut ditujukan untuk memenuhi perintah Allah dalam meraih keridhaan-Nya. Jika ada orang yang mengingkari perintah Allah, maka dia menjadi kafir dan murtad dari agama Islam. ${ }^{2}$ Dalam ibadah haji, terdapat beberapa syarat wajib haji, di antaranya sudah baligh, berakal, merdeka, dan mampu, baik dari segi biaya, sehat, maupun aman dalam perjalanan. Barang siapa yang tidak memiliki kemampuan biaya, maka ia tidak wajib melaksanakan haji. Jika seseorang memiliki hutang, maka ia wajib melunasi hutangnya, kemudian baru melaksanakan ibadah haji, karena melepaskan diri dari tanggungan lebih utama didahulukan. Jika seseorang lemah fisiknya sehingga tidak mampu melaksanakan haji sendiri, sementara ia mempunyai harta, jika kelemahan fisiknya itu bersifat permanen dan tidak bisa diharapkan sembuh, maka ia bisa menunjukkan orang lain untuk mewakilinya melaksanakan ibadah haji.

Para ulama sepakat bahwa bisa atau mampu itu merupakan syarat wajib haji, berdasarkan firman Allah dalam surat Ali-Imran di atas, tetapi mereka berbeda pendapat tentang arti 'mampu' itu. Imam Asy Syafi'i berkata;

${ }^{2}$ Abu malik kamal bin Sayyid Salim, Fiqhus Sunnah lin Nissa', Jilid. 1, Jakarta: AlI'tisham Cahaya Umat, 2007, hlm. 401. 


\section{ومن لم يكن في ماله سعة يحج بها من العيل غير أن يستقرض فهو لال يجد السبيل}

Artinya: "Barangsiapa yang tidak memiliki kelapangan harta untuk haji, selain dengan hutang, maka dia tidak wajib untuk menunaikannya.",3

Kata mampu atau bekal adalah kebutuhan yang berupa biaya untuk pergi, makan, minum, sewa tempat, uang untuk mengurus passport, dan sebagainya dari beberapa hal yang dibutuhkan pada keadaan dan kondisi tersebut, dengan syarat semuanya itu melebihi hutang-hutangnya dan kebutuhan-kebutuhan keluarganya, serta kebutuhan-kebutuhan yang sangat mendesak dari sumber mata pencahariannya, seperti bumi untuk pertanian, dan alat-alat kerja bagi pekerja, dan modal untuk berdagang, Dalam hal ini, hanya imam Malik yang berbeda pendapat, beliau mengatakan bahwa, barang siapa yang mampu berjalan kaki, maka dia wajib haji, sebagaimana diwajibkan untuk memberi nafkah kepada sanak saudaranya, dan keluarganya, tidak terkecuali. Dia wajib menjual apa saja yang dibutuhkan untuk naik haji, baik berupa alat-alat mata pencaharian dari bumi, binatang ternak, maupun alatalat lainnya, bahkan sampai pada buku-buku dan hiasan-hiasan yang dipakainya. $^{4}$

\footnotetext{
${ }^{3}$ Imam Asy Syafi'i, Al-Umm, Juz. 1, hlm. 127.

${ }^{4}$ Muhammad Jawad Mughniyah, AlFiqhu 'Ala al-Madzahib al-Arba'ah, Beirut: Dar al-Jawad, 2002, hlm. 207.
}

Ulama saudi Syeikh al-Jabrin menjelaskan, bahwa pengertian kemampuan haji adalah orang yang mampu sampai ke mekkah dengan cara apapun maka dia wajib haji dan umrah. Jika dia mampu dengan berjalan dan membawa bekalnya, maka dia wajib haji. Jika seseorang mempunyai biaya transportasi modern seperti kapal laut, pesawat dan mobil, maka dia wajib haji. Jika dia mendapatkan bekal dan kendaraan, tapi tidak mendapatkan orang yang dapat menjaga harta dan keluarganya, atau tidak mendapatkan apa yang dia nafkahkan kepada keluarganya selama dia pergi haji, maka dia tidak wajib haji karena dia tidak mempunyai kemampuan. Demikian pula jika di jalan terdapat sesuatu yang menakutkan atau ditakutkan seperti perampok, atau diharuskan membayar pajak mahal, atau waktunya tidak cukup untuk sampai ke mekkah, atau tidak mampu naik kendaraan apapun karena sakit atau akan mendatangkan mudharat lebih berat, maka kewajiban hajinya gugur dan dia wajib menggantikannya kepada orang lain, jika dia mempunyai kemampuan harta, jika tidak, maka tidak wajib hajinya. ${ }^{5}$

Memang ulama berbeda pendapat apakah pelaksanaannya harus pada tahun terpenuhinya syarat-syarat sebagaimana pendapat imam Abu Hanifah dan sejumlah ulama lain atau dapat ditangguhkan ketahun-tahun berikut sebagaimana pendapat imam

5 Muhammad bin 'Abdul 'Aziz alMusnad, Fatwa-fatwa Haji dan Umrah, Bogor: Pustaka Imam as-Syafi'i, 2003, hlm. 34. 
Syafi'i, Malik dan mayoritas ulama. Karena kewajiban haji ditetapkan Allah jauh sebelum nabi melaksanakan haji wada'. Menurut sementara ulama haji diwajibkan pada tahun ke-3 hijrah, atau tahun ke-5 ada juga yang berpendapat pada tahun ke-9, sedang nabi melaksanakan haji beberapa bulan sebelum beliau wafat pada tahun 11 hijrah. Memang sebelum adanya kewajiban ini - yakni ketika beliau berada di mekkah - beliau pernah dua kali melaksanakan ibadah haji, tetapi mengikuti ajaran Nabi Ibarahim as. Dan sebagai pendekatan diri kepada Allah swt. Menurut madzhab Syafi'i, Tsauri, Auza'i dan Muhammad bin Hasan, kewajiban haji itu boleh dengan ditangguhkan; artinya ia dapat dilakukan pada sembarang waktu selagi hidup, dan yang berkewajiban tidaklah berdosa menangguhkannya asal saja ditunaikannya sebelum ia meninggal dunia. Alasannya ialah karena Rasulullah saw. Menanguhkan pelaksanaan hajinya berikut para istri dan kebanyakan sahabatnya sampai pada tahun $10 \mathrm{H}$, padahal mulai diwajibkannya ialah pada tahun $6 \mathrm{H}$, seandainya harus dikerjakan dengan segera, tentulah Nabi saw, tidak akan menangguhkannya. Berkata Syafi'i: "Dari keterangan itu kita mengambil alasan bahwa haji itu wajibnya hanya sekali seumur hidup, mulai dari waktu baligh dan kesempatan berakhir sebelum mati". 6

Dari penjelasan di atas menimbulkan beberapa masalah

6 Mahyuddin Syaf, Fiqih Sunnah, Jilid. 5-8, Kuala Lumpur: Victory Agencie, 2001, hlm. 34 tentang pendapat ulama tentang konsep istista'a dan apa kriteria istista'a tersebut. Untuk itu penulis ingin mengangkat permasalahan ini dalam bentuk skripsi dengan judul "kriteria istitha'ah dalam berhaji (kajian fiqh kontemporer)"

\section{B. Rumusan Masalah}

Berdasarkan latar belakang masalah yang telah diuraikan di atas, maka yang menjadi rumusan masalah adalah; Bagaimana ukuran dan batasan istitha'ah dalam berhaji menurut fiqh kontemporer?

\section{Metode Peneltian}

Pada dasarnya dalam setiap penulisan karya ilmiah, data yang lengkap serta objektif sangat diperlukan, hal ini tentunya harus sesuai dengan metode yang akan digunakan dalam penelitian ini nantinya.

1. Jenis Penelitian

Dalam pembahasan skripsi ini, penulis menggunakan metode deskriptif analisis yaitu suatu metode yang bertujuan membuat deskripsi, gambaran atau lukisan secara sistematis, faktual, dan akurat mengenai fakta-fakta, sifat-sifat serta hubungan antar fenomena yang diselidiki. $^{7}$ Ini dilakukan setelah melaui proses analisa data-data yang diperoleh dari pembahasan. Di mana dalam penulisan ini akan menjelaskan ukuran, batasan dan kriteria istitha'ah

7 Surmadi Suryabrata, Metodologi Penelitian, Jakarta: PT Raja Grafindo Persda, 2008, hlm. 75. 
dalam berhaji menurut fiqh kontemporer.

2. Tehnik Pengumpulan Data

a. Data Primer

Data primer merupakan sumber

data yang sangat penting dan diutamakan dalam suatu penelitian/pembahasan sebagai dalil yang kuat. Teknik pengumpulan data primer dilakukan kajian pustaka (library research), yaitu dengan mempelajari Al-Quran, hadist dan kitab-kitab fiqkh yang berkaitan dengan bab haji serta buku-buku lain yang ada kaitannya dengan permasalahan dalam skripsi ini.

b. Data sekunder

Data Sekunder ialah data pelengkap dalam penelitian ini penulis merujuk pada karangan ilmiah lain yang berkaitan dengan objek yang penulis kaji, yang berhubungan dengan haji. Data ini bertujuan untuk mengetahui dan mendapatkan penjelasan yang lebih jelas tentang kriteria istitha'ah dalam berhaji.

3. Langkah Analisis Data

Pembahasan skripsi ini menggunakan metode deduktif dimana data yang telah berhasil dihimpun akan dianalisis secara kualitatif dengan menggunakan metode deskriptif, yaitu memaparkan data-data yang terkait dengan masalah yang dibahas yang ditemukan dalam berbagai literatur dan kesimpulannya diambil melalui logika deduktif yaitu memaparkan masalahmasalah yang bersifat umum kemudian ditarik suatu kesimpulan yang bersifat khusus. Metode ini digunakan sebagai metode analisis berdasarkan teori umum yang pasti kebenarannya, dalam penelitian kali ini tentang kriteria istitha'ah dalam berhaji (kajian fiqh kontemporer).

Dalam penyusunan dan penulisan skripsi ini berpedoman kepada buku Pedoman Penulisan Karya Ilmiah Mahasiswa dan Pedoman Transliterasi Arab Latin, yang diterbitkan oleh Fakultas Syariah IAIN Ar-Raniry Darusalam Banda Aceh Tahun 2002. Sedangkan untuk penerjemahan ayat-ayat Al-Quran dikutip dari Al-Quran dan Terjemahannya yang diterbitkan oleh yayasan penyelenggaraan Penterjemahan Al-Quran Kementerian Agama RI tahun 1990

\section{HASIL PENELITIAN}

Kesanggupan atau yang dikatakan istitha'ah dalam ayat AlQuran yang menjadi salah satu syarat wajib haji. Barulah dipandang telah terwujud istitha'ahh (kemampuan) bagi orang yang menunaikan haji, apabila telah terdapat hal-hal berikut ini:

1. Yang menghadapi perintah haji itu seorang yang mukallaf yang sehat badan. Maka jika dia tidak sanggup melaksanakan ibadah haji, karena telah sangat tua, atau sakit yang tidak dapat bergerak dan tidak dapat beralan lagi, wajiblah atasnya menurut sebahagian pendapat ulama untuk menyuruh orang lain melakukan hajinya jika dia mempunyai harta. ${ }^{8}$

2. Perjalanan yang ditempuh aman dari segala bahaya, baik terhadap

8 Muhammad Ali Ash-Shiddieqy, Pedoman Haji, Semarang: Pustaka Rizki Putra, 1999, hlm. 18. 
jiwa, ataupun harta. Maka jika ditakuti bahaya atau bencana di perjalanan, seperti perampokan, ataupun penyakit yang sedang berjangkit, maka masuklah ia ke dalam golongan orang yang tidak sanggup berhaji. ${ }^{9}$ Bila dilihat kondisi sekarang ini, khususnya aman dalam perjalanan tidak relevan lagi untuk digolongkan kedalam kriteria mampu (istitha'ah), karena jalan yang ditempuh berbeda dengan 14 abad yang silam, yang perjalanannya masih menggunakan transportasi darat dengan berjalan kaki, dan kondisi tanah arab yang belum stabil dari segala aspek.

3. Ada alat angkutan/transportasi untuk pulang pergi, baik darat, laut atau udara. Karenanya tidaklah wajib haji atas orang yang tidak sanggup berjalan kaki karena jauh jalan yang ditempuh. Dalam keadaan itu adanya kendaraan tidaklah menjadi syarat bagi orang yang dekat tempatnya dengan Mekkah yang sanggup ditempuh dengan jalan kaki, yaitu jarak yang kurang dari masafah qasar. Orang yang tidak dapat menguasai binatang kendaraannya, tidak dapat mengendalikan kudanya dan tidak mendapat kendaraan yang dapat ditungganginya, tidaklah wajib atasnya haji. ${ }^{10}$

4. Memiliki perbelanjaan. Dalam hal perbelanjaan ini, hendaklah ada perbelanjaan yang mencukupi bagi kebutuhannya untuk memelihara

${ }^{9}$ Ibid,

${ }^{10}$ Ibid kesehatan tubuhnya dan kebutuhan orang-orang yang dipikul belanjanya, yang lebih dari keperluan-keperluan pokok, yaitu pakaian, tempat tinggal, kendaraan dan lain-lain alat bekerja, hingga selesai melaksanakan tugasnya dan kembali. ${ }^{11}$ Memiliki bekal dan kendaraan, yang sangat diperhatikan disini adalah cukupnya bekal untuk diri pribadinya yang dalam tanggungannya. Cukup disini berarti lebih dari kebutuhankebutuhan pokok, tempat kediaman dan sarana pencaharian, mulai saat keberangkatan sampai ia kembali. ${ }^{4}$ Kendaraan yang pantas dengan keadaannya, baik kepunyaannya sendiri maupun dengan jalan menyewa. Syarat bagi orang yang jauh tempatnya dari Mekkah dua marhalah $(80,640$ $\mathrm{Km})$. Orang yang jaraknya dari Mekkah kurang dari itu dan dia sanggup berjalan kaki maka, kendaraan tidak menjadi masalah lagi. ${ }^{12}$

Mengenai masalah ini, Nabi Muhammad Saw telah menafsirkan firman Allah "sabil" yang berkenaan dengan haji ini dengan "pembelajaan dan kendaraan”. Kemampuan atau istitha'ah ini tidaklah hanya dilihat kesanggupan yang diperlukan untuk melaksanakan ibadah-ibadah yang lain, seperti puasa, dan shalat, tetapi dilihat juga kesanggupan-kesanggupan

\footnotetext{
${ }^{11}$ Ibid

12 Rasyid Sulaiman, al-Fiqh al-Islam,
} Bandung: PT.Sinar Baru Algensindo, 1994, hal. 249 
dari segi perbelanjaan dan kendaraan (transportasi).

Walaupun mengenai masalah tersebut terdapat hadist-hadist yang menafsirkan sabil dengan pembelanjaan dan kendaraan itu dhai'f bila ditinjau dari segi sanadnya, sebagaimana telah diungkapkan Imam Ibnu Taimiyah dalam bab sebelumnya, namun kebanyakan ulama mensyaratkan yang demikian untuk mewajibkan haji. Adanya perbelanjaan dan kendaraan adalah bagi yang rumahnya jauh dari kota Mekkah. Maka bagi orang yang tidak memperoleh perbelanjaan dan kendaraan, tidaklah wajib haji atasnya.

Ibadah haji itu adalah suatu ibadah yang untuk mengerjakannya kita harus menempuh jarak yang jauh. Maka untuk melaksanakannya diperlukan kesehatan fisik, perbelanjaan yang memadai dan kendaraan, sama halnya dengan jihad.

Asy-Syirazi dalam alMuhazzab mengatakan bahwa; jika seseorang membutuhkan uang yang dapat dipergunakan untuk belanja ke Mekkah dan kendaraan, sedang dia membutuhkan uang itu karena ada hutangnya, maka tidaklah wajib atasnya mengerjakan haji, sebaiknya hutang itu harus dilunasi dengan segera, ataupun ditangguhkan. Dan jika ia memerlukan uang untuk membeli rumah atau ongkos khadam yang dibutuhkan, maka tidaklah wajib dia mempergunakan uang itu untuk keperluan haji. Demikian pula jika uang itu diperlukan untuk keperluan perkawinan, untuk menghindari perzinaan. Kalau uang itu dipergunakan untuk keperluan dagang buat mendapatkan hasil yang banyak, maka menurut pendapat Ibnu Syuraij, tidak juga wajib. ${ }^{13}$

Asy-Syaikh Muhammad bin Shalih Al-Utsaimin berkata: "Mempunyai kemampuan dalam bentuk harta dan fisik, yakni memiliki harta yang dapat mencukupi untuk berangkat haji berikut kepulangan (mampu membayar ONH), serta segala kebutuhan dalam perjalanan haji. Harta yang dimiliki tersebut adalah harta yang tersisa setelah dikurangi pembayaran hutang, nafkah yang bersifat wajib bagi segala kebutuhan hidup keluarga yang ditinggalkan selama perjalanan haji. Maksudnya harta tersebut disyaratkan tidak diambil dari jatah nafkah orang-orang yang harus ia tanggung, yaitu selama perjalanan pulang pergi pada pelaksanaan ibadah haji.

Mengenai masalah tersebut di atas yaitu, persyaratan bahwa harta (pembekalan) itu harus diambil dari selain jatah rumah, pembantu rumah tangga (jika ada), biaya kesehatan atau hal-hal lain yang diperlukan. Sebagaimana pula baju yang harus tersedia sesuai dengan tingkat pangkatnya. Oleh karena itu, jika ia mempunyai uang, maka ia boleh mengalokasikan uang itu untuk hal tersebut. Demikian ini jika rumah dan pembantu tersebut memang sangat ia butuhkan. Namun jika ia bisa menjual sebagian rumah yang ia miliki, sehingga mencukupi biaya haji, atau harga rumah tersebut terlalu mahal sehingga tidak layak dengan harga beli, dan sekiranya ia tukarkan rumah 
tersebut dengan selisih harga yang bisa mencukupi biayanya, maka ia tetap wajib haji. ${ }^{14}$

Jika seseorang tidak mampu dari sisi hartanya, maka dia tidak wajib berhaji. Dan jika berkemampuan dari sisi harta namun kondisi kesehatannya lemah, maka perlu untuk ditinjau terlebih dahulu. Jika rasa lemahnya itu dimungkinkan bisa hilang, seperti sakit yang dimungkinkan kesembuhannya maka hendaknya dia bersabar hingga mendapatkan kesembuhan, lalu menunaikan ibadah haji, jika waktunya masih memungkinkan. Dan jika rasa lemahnya itu dimungkinkan tidak bisa hilang dikarenakan faktor ketuaan dan penyakit menahun yang sulit untuk disembuhkan misalnya, maka hendaknya mewakilkan hajinya kepada orang lain.

Seseorang mempunyai uang yang sudah mencukupi untuk biaya haji, dan hal-hal lain yang dibutuhkan, seperti nafkah keluarganya. Kemudian ia ingin menikah karena takut kepada perzinaan, maka mengalokasikan dana tersebut untuk menikah adalah lebih penting dari pada mengalokasikan dana tersebut untuk biaya haji. Namun dalam masalah ini, didapatkan juga sebahagian ulama yang berpendapat bahwa, kewajiban megerjakan haji ketika semua persyaratannya telah terpenuhi itu lebih utama dari pada menikah. Para ulama yang mengatakan lebih utama untuk menikah, mereka beralasan, bahwa kebutuhan seseorang untuk menikah lebih mendesak,

14 Imam Abu Zakariyya Yahya, Raudhatul Thalibin, (terj. A. Shalahuddin, dkk), Jakarta: Pustaka Azzam, 2007, hlm. 449. sedangkan haji adalah kewajiban yang bisa ditunda. Maka orang tersebut tidak harus haji jika kondisinya memang seperti itu, tapi hendaknya ia alokasikan semua kemampuannya untuk pernikahan. ${ }^{15}$

Allah Swt mewajibkan haji bagi umat Muslim yang sudah mampu secara fisik dan finansial untuk menunaikan ibadah haji. Namun jika ada kelompok masyarakat bergotong royong secara ikhlas membiayai anggota kelompoknya untuk berangkat haji, maka hajinya tetap sah meski ia secara pribadi belum berkewajiban menunaikan ibadah haji. Syaratnya, tidak ada paksaan, tidak gambling, dan tidak ada unsur riba. Orang yang bersedekah pun mendapat pahala dari harta yang dikeluarkan. tapi jangan sampai di antara harta yang dikumpulkan ada harta zakat yang diberikan, karena zakat tidak boleh digunakan untuk berangkat dan memberangkatkan ibadah haji. ${ }^{16}$

5. Syarat wajib haji bagi perempuan adalah pergi bersama dengan suami atau mahram atau wanitawanita yang dipercaya. (Qaul yang masyhur dari Syafi'i). Di Indonesia seorang wanita didaftarkan sebagai mahram bagi seorang wanita lain yang sama-sama tidak mempunyai mahram laki-laki. Adapun orangorang yang membolehkan perempuan pergi haji tanpa mahram ini mengambil alasan dari

\footnotetext{
15 Ibid,

${ }^{16}$ Imam Abu Zakariyya Yahya, Op.cit, hlm. 427.
} 
"peristiwa, isteri-isteri Nabi Saw mengerjakan haji setelah mendapat izin dari khalifah Umar bin Khattab, yakni waktu haji terakhir yang dilakukan mereka. Yang dikirim untuk mendampingi mereka adalah Ustman bin Affan dan Abdurrahman bin Auf. Ustman menyeru waktu itu jangan ada yang mendekati atau yang memandang mereka, mereka berada dalam sekedup-sekedup di atas unta. ${ }^{17}$

Mengenai permasalahan ini dalam Al-Quran sendiri tidak terdapat nash yang menunjukkan penjelasan keharusan haji seorang wanita disertai mahramnya. Namun dalam hadist Nabi banyak ditemukan penjelasan tentang keharusan seorang perempuan yang hendak menunaikan haji harus disertai mahramnya, yaitu yang seluruhnya bersumber dari 'Abd Allah bin 'Abbas melalui 4 mukharrij (Bukhari 4 hadist, Muslim 4 hadist, Ahmad 3 hadist dan Ibn Majah 1 hadist), sebagaimana hadist-hadist yang sebahagiannya telah penulis sebutkan dalam bab sebelumnya.

Sedangkan dari aspek matan, tidak ada bukti historis yang menunjukkan bahwa itu bukan hadist Rasulullah Saw. Realitas historissosial-kultural empat belas abad silam pada masa kehidupan nabi, tentu sangat jauh berbeda dengan saat ini. Saat ini, dengan transportasi udara yang semakin canggih, umat Islam dari negara manapun bisa sampai ke tanah suci dalam hitungan

17 Sayyid Sabiq, Fiqh al-Sunnah, Darul al-Fikr, Bairut: tt, Juz 5, hal. 44 jam. Sarana transportasi darat pun dengan mudah didapat. Tersedianya alat komunikasi yang canggih.

Tempat-tempat ibadah dan fasilitas umum yang telah dilengkapi berbagai fasilitas yang memberi kenyamanan jama`ah, serta adanya hotel-hotel berbintang juga siap menyediakan berbagai fasilitas kemudahan bagi jama`ah haji.

Sementara 14 abad silam, dengan sarana transportasi yang sangat tradisional (berjalan kaki, naik kuda ataupun unta), membuat jarak antara Makkah-Madinah ditempuh dalam waktu 8 hari perjalanan. Bagaimana dengan umat Islam yang domisilinya lebih jauh dari itu? Belum lagi medan perjalanan yang cukup berat, kondisi keamanan yang tidak menjamin serta kultur yang memposisikan perempuan sebagai pihak yang lemah dan harus dilindungi keluarganya. Dengan adanya rentang waktu ataupun rentang wilayah yang cukup panjang yang harus dilalui, sangatlah mungkin Rasulullah Saw mengharuskan haji perempuan disertai mahramnya, untuk melindungi perempuan, dan untuk keamanan perempuan.

Untuk mengkontektualisasikan keberadaan mahram bagi perempuan dalam berhaji, beberapa hal yang harus dipertimbangkan adalah:

Kewajiban haji merupakan kewajiban bagi laki-laki dan perempuan yang "mampu", tanpa pandang jenis kelamin. (2) Konteks historis keharusan mahram masa Rasulullah terkait dengan aspek keamanan dan perlindungan terhadap perempuan saat 
itu. (3) Relativitas jarak perjalanan yang mengharuskan disertai mahram. (4) Para isteri Rasulullah, memahami hadist tersebut tidak secara tekstual. (5) Relativitas kepemilikan mahram, menjadikan pemahaman keharusan disertai mahram dalam bepergian secara umum, maupun berhaji secara khusus tidak bisa dipahami secara mutlak.

Meski keberadaan mahram masa Rasulullah, sangat terkait dengan aspek keamanan dan perlindungan terhadap perempuan, namun "ide dasar" hadist tersebut terletak pada sesuatu yang lebih mendasar, yakni terealisasinya sesuatu yang dapat membantu pelaksanaan ibadah haji dengan baik. Pada masa Rasulullah, keberadaan mahram secara fisik sangat diperlukan perempuan agar dapat beribadah haji dengan tenang dan khusyu`. Namun, dalam konteks yang berbeda, sesuatu yang dapat membantu terealisasinya ibadah haji dengan baik bisa dalam bentuk yang berbeda-beda pula.

Dalam realitas historis empiris masyarakat sekarang, seperti masyarakat Indonesia khususnya, pemahaman tentang keharusan perempuan disertai mahram dalam bepergian maupun haji semakin memudar, kecuali kelompokkelompok fundamentalis, yang masih memahami mahram secara tekstual. Hal ini disebabkan akses perempuan ke dunia luar semakin luas, baik secara kuantitas maupun kualitas. Perempuan keluar rumah sendiri untuk sekolah, kuliah, bekerja ataupun kegiatan sosial dan keagamaan merupakan hal biasa.
Tidak lagi dipermasalahkan perempuan bepergian sendiri ke luar kota, luar pulau, bahkan keluar negeri dalam waktu singkat maupun lama (untuk kepentingan studi maupun bekerja). Inilah di antara hal-hal yang memberi andil tidak dipermasalahkannya perempuan bepergian tanpa mahram. ${ }^{18}$

Secara "kultural" masyarakat yang telah membuka akses perempuan ke dunia luar, menjadikan keberadaan "mahram" saat ini telah mengalami beberapa pergeseran. Keberadaan "mahram" yang memiliki arti khusus kerabat yang haram dinikahi untuk menjaga keamanan perempuan telah bergeser pada pengertian "untuk menemani". Sehingga tidak jarang dipasangkannya seorang jama`ah haji perempuan dengan seorang laki-laki, bukan karena hubungan mahram, tetapi hubungan famili jauh, teman, tetangga, atau satu desa yang sudah dikenalnya. ${ }^{19}$

Di samping itu, dalam fenomena masyarakat sering terjadi perempuan pergi haji "untuk menemani laki-laki"; ayahnya, paman atau mertua laki-lakinya, dan bukan sebaliknya. Seorang laki-laki yang sudah tua, akan lebih merasa tenang ditemani salah satu keluarganya yang perempuan, karena lebih bisa menjaga dan merawatnya. Banyak

18 Mas'udi, Masdar F, Islam dan Hak-hak Reproduksi Perempuan, Bandung: Mizan, 1997, hlm. 57.

19 Umar, Nasaruddin, Argumen Kesetaran Gender Perspektif Al-Qur'an, Jakarta: Paramadina, 1999. hlm. 79. 
juga jama`ah laki-laki yang lebih merasa percaya diri dan tenang, ketika ditemani isteri atau keluarganya. Realitas di masyarakat dengan berbagai bentuknya, "perempuan ditemani laki-laki" atau "laki-laki ditemani perempuan" sebenarnya merupakan hal yang biasa saja. Karena secara psikologis, bepergian jauh dalam kurun yang lama di tempat yang masih asing, seseorang pada dasarnya membutuhkan "kawan bicara" yang sudah dikenal sebelumnya. Secara khusus pula, konteks Indonesia, pelaksanaan ibadah haji tidak dilakukan secara perseorangan, namun senantiasa bersama-sama dengan rombongan (kloter), di bawah koordinasi Departemen Agama RI sebagai pemegang policy.

Oleh karenanya, berbagai fasilitas yang disediakan oleh pemerintah maupun biro perjalanan haji milik swasta, pengurusan administrasi, bimbingan haji, transportasi, akomodasi, konsumsi, penginapan, layanan informasi, layanan kesehatan, serta berbagai fasilitas, seperti alat komunikasi maupun kartu kredit, yang memegang kunci utama dalam menjamin keamanan dan kenyamanan ibadah haji secara maksimal menggantikan posisi "mahram" dalam pengertian fisik.

\section{KESIMPULAN}

Dari beberapa analisa yang terdapat pada bab-bab di atas, maka penulis dapat menyimpulkan:

1. Istitha'ah (kemampuan) merupakan syarat wajib ibadah haji, baik secara finansial, fisik, maupun memenuhi keperluan dalam perjalanan. Mampu secara finansial, artinya mampu membayar biaya perjalanan dan biaya kehidupan keluarga yang ditinggalkan. Sedangkan mampu secara fisik artinya mampu dalam melakukuan perjalanan, selama dalam melakukan ibadah haji. Adapun kemampuan perjalanan haji yaitu mampu untuk memenuhi persyaratan perjalanan haji, seperti keperluan transfortasi dan imigrasi serta kondisi perjalanan yang aman. Arti lain dari kemampuan finansial adalah memiliki biaya ibadah haji dengan dirinya sendiri. Orang yang belum memiliki harta yang dimiliki dari dirinya sendiri belum diwajibkan untuk melaksanakan ibadah haji. Bahkan kalau ada orang yang memberinya uang agar berangkat haji, maka dia tidak wajib menerimanya, karena itu bukan termasuk kemampuan (istitha'ah) pada dirinya sendiri.

2. Bagi orang yang ingin melaksanakan ibadah haji, selama waktu pelaksaannya harus terbebas dari pekerjaan/tugas yang diembankan kepadanya, yang tugas tersebut tidak boleh ditunda atau digantikan oleh orang untuk mengerjakannya, seperti pegawai negeri/swasta atau narapidana yang sedang menjalankan masa hukuman. 


\section{DAFTAR PUSTAKA}

Abdul 'Azim bin Badawi alKhalafi, al-Wajiz, (terj. Ma'ruf Abdul Jalil), Jakarta: Pustaka as-Sunnah, 2006

Abdul Halim Hasan, Tafsir alAhkam, cet.I, Jakarta: Kencana, 2006

Abuddin Nata, Masail alFiqhiyah, Bogor: kencana, 2003

Abdur Rahman Al-Jaziri, Mazhab Arba'ah, Cet. I, Beirut: Dar Ihyaut Turats Al-Araby, 2003

Abu Malik Kamal bin Sayyid Salim, Fiqhus Sunnah lin Nissa', Jilid. I, Jakarta: Al-I'tishom Cahaya Umat, 2007

Ahmad Warson Munawwir, Kamus al-Munawir, Surabaya: Pustaka Progressif, 2002

Rahman Ritonga, Zainuddin, Fiqh Ibadah, Jakarta Selatan: Gaya Media Pratama, 1997

Departemen Agama RI, AlQur'an dan terjemah, Dirjen Bimas Islam Depag, 1998

Djmaluddin Dimjati, Panduan Ibadah Haji dan Umrah Lengkap, Solo: Era Intermedia, 2006

Fatwa Majelis Ulama Indonesia Nomor: 01 Tahun 2001 tentang Haji bagi Narapidana
Ibnu Rusyd, Bidayatul Mujtahid, (terj. Beni Sarbeni, dkk), Jakarta: Pustaka Azzam, 2006

Imam Abu Zakariyya Yahya, Syarah An-Nawawi, (terj. A.Shalahuddin, dkk), Jakarta: Pustaka Azzam, 2007

Imam Abu Zakariyya Yahya, Raudhatul Thalibin, (terj. A.Shalahuddin, dkk), Jakarta: Pustaka Azzam, 2007

Imam Jalaluddin al-Mahalli, Imam Jalaluddin as-Suyuti, tafsir jalalain, jilid 1, Bandung: Sinar Baru Algensido, 2006

Imam Muslem, Sahih alMuslim, (terj. Elly Lathifah), Jakarta: Gema Insani, 2005

Ismail Bin Katsir Al Qurasyi Ad-Dimasyqy, Tafsir Ibnu Katsir, Juz I, Singapura: Sulaiman Maz’i, 2004

Jawadi Amuli, Hikmah dan Haji, Cet. 2. Bogor: Cahaya, 2004

Muhammad Abdul Fattah alBanhawi, Taarikh At Tasyrii' Al Islami, 2001

Muhammad Ali As-Sabuni, Tafsir Ayat Ahkam, Cairo: Dar asSabuni, 2007

Muhammad Hasbi AshShiddieqy, Pedoman Haji, Cet.3, Semarang: PT.Pustka Rizki Putra, 1999 
Muhammad bin Abdul Azis alMusnad, Fatwa-fatwa Haji dan Umrah,( terj. Asmuni Solihin Zamakhsyari), Bogor: Pustaka Imam Asy-Syafi'i, 2003

Muhammad bin 'Abdul 'Aziz al-Musnad, Fatwa-fatwa Haji dan Umrah, Bogor: Pustaka Imam asSyafi'i, 2003

Muhammad Hasbi ashShiddieqy, Tafsir an-Nuur, Jilid I, Semarang: PT. Pustaka Rizki, 2001

Muhammad Ali AshShiddieqy, Pedoman Haji, Semarang: Pustaka Rizki Putra,1999

Muhammad Ismail al-Amiru alYamaniy ash-shan'ani, Subulu asSalam Syarhi Bulughul Maram, Cairo: Dar al-Hadis, 2005

Muhammad Jawad Mughniyah, Al-Fiqhu 'ala Al-Madzahib AlArba'ah, Beirut: Dar al-Jawad, 2002

M. Quraish Shihab, Tafsir alMisbah, jilid II, Jakarta: Lentera Hati, 2002

Mahyuddin Syaf, Fiqih Sunnah, Jilid. 5-8, Kuala Lumpur: Victory Agencie, 2001

Mas'udi, Masdar F, Islam dan Hak-hak Reproduksi Perempuan, Bandung: Mizan, 1997
M. Quraish Shihab, Tafsir alMisbah, Tanggerang: Lentera Hati, 2007

Rasyid Sulaiman, al-Fiqh alIslam, Bandung: PT.Sinar Baru Algensindo, 1994

Saleh al-Fauzan, Fiqih Seharihari, Cet. 1. Jakarta: Gema Insani Press, 2005, hlm. 307

Said Agil Husaini al-Munawar, Abdul Halim, Fikih Haji Menuntut Jama'ah Mencapai Haji Mabrur, Jakarta: Ciputat Press, 2003

Shalih bin Fauzan bin Abdullah Ali Fauzan, ringkasan Fiqh Syaikh Fauzan, (terj. Kamaluddin Sahar), Jakarta: Pustaka Azzam, 2006

Sayyid Sabiq, Fiqh Sunnah, jilid III, terj, (Abdurrahim, Masrukhin),Jakarta: Cakrawala Publishing, 2008

Umar, Nasaruddin, Argumen Kesetaran Gender Perspektif AlQur'an, Jakarta: Paramadina, 1999

Wahbah al-Zuhaili, Fiqh Islam Waadilatuh, (terj. Ahmad Sayed Hussain, dkk), Malaysia: Yayasan Pembangunan Ekonomi Islam Malaysia, 2002

http://www.

Republika.co.id/koran-detail

Yahya bin Abil Khoir Salim Al-Imroni, Al-Bayan Fi Madzhabi Al- 
Imam As-Syafi'I, Juz IV, Darul Minhaj

Yusuf al-Qaradhawi, Fatwafatwa Kontemporer, terj (Samson rahman, Dkk), Jakarta: pustaka alKautsar, 2002 